\title{
Mosquito release blocked by fearful California residents
}

\section{Berkeley}

A public outcry from a Los Angeles, California, community has halted plans for an experiment to study population characteristics of mosquitoes in an urban environment. The experiment called for the release of some 20,000 mosquitoes in the city of Norwalk on 6 September. Ironically, an experiment involving the release of twice as many mosquitoes in a neighbouring community went off without a hitch earlier this summer.

Interest in Los Angeles mosquitoes, especially those in the Norwalk area, arises from an outbreak or St Louis encephalitis virus that occurred in 1984 and resulted in the death of a Norwalk resident. Richard P. Meyer of the University of California arbovirus field station in Bakersfield, California, says three mosquitoes found in the Los Angeles basin are known to. act as vectors for the virus: Culex quinquefasciatus

\section{Loma Linda halts controversial trial \\ Berkeley}

Loma Linda University Medical Center in southern California last month suspended its programme of keeping infants born only with a brain stem alive on life support systems in the hopes of using their organs for transplantation (see Nature 330, 592; 1987). Such anencephalic babies normally do not survive long after birth.

Joyce Peabody, chief of neonatology, said last week that twelve infants were studied under a protocol established late last year. At first, infants were placed on life-support systems immediately after birth, but after six births it became clear that life support intended to preserve the heart and lung was also supporting the brain stem, prolonging life. The final six infants were placed on life-support systems only when death was imminent, but this too interrupted the normal dying process, preserving some brain-stem function. Organs may be removed only following brain death, and no organs were obtained from the infants in the protocol that could be used for transplantation.

Loma Linda has had a vigorous programme of neonatal organ transplants. Peabody says that despite not obtaining usable organs, the programme was a success because it brought out some of the medical and social issues that will have to be considered in using anencephalic infants as organ donors. The medical centre has not decided whether it will resume the programme. Joseph Palca (southern house mosquito), $C$. tarsalis (western encephalitis mosquito) and $C$. peus (foul water mosquito).

At the request of the Southeast Mosquito Abatement District, Meyer and his colleagues at the University of California School of Public Health in Berkeley have been studying these mosquitoes in an attempt to establish how the encephalitis outbreak occurred, and why it has not recurred. Meyer says one crucial factor is the extrinsic incubation period. The mosquitoes commonly pick up the virus from infected birds, but it takes some time before the virus appears in sufficient quantities in the mosquito saliva to be transmitted to another vertebrate. Warmer temperatures seem to shorten the incubation, and 1984 was a particularly hot, wet summer in Los Angeles.

Although there have been many controlled release studies in rural environments, urban mosquito studies are rare. For the Los Angeles basin experiments, mosquitoes were to be collected locally, tagged with a fluorescent dust, released from one or two locations and then recaptured in traps scattered around the city. That is how things worked in June for an experiment in Rossmore, up the San Gabriel river from Norwalk.

But not all urban environments are equally hospitable to mosquitoes. Unattended backyard pools, outdoor flower pots and drainage ditches make suitable breeding grounds, but these vary in number, in part because of the relative affluence of the community involved and how well its water supply is managed. More experiments were needed in a different kind of community.

The researchers chose Norwalk and, given their experience in Rossmore, expected no problems. But when Jack Hazelrigg of the Mosquito Abatement District appeared before the Norwalk City Council to explain the experiment, he was lampooned in the local press as planning to release "killer mosquitoes" on an unsuspecting populace with the blessing of local elected officials. Despite assurances that the experiment was extremely benign, and unlikely even to result in increased mosquito bites, let alone cases of encephalitis, the Mosquito Abatement District cancelled the planned release, and there are no plans to reschedule it.

Hazelrigg says that most people would probably never have noticed the experiment, and it is ludicrous to think that his agency would release "killer" mosquitoes. But a small, vocal minority has spoken up loudly, and, says Hazelrigg, "the squeaky wheel got the grease". Joseph Palca

\section{AIDS test for one-in-three newborns}

\section{Washington}

THE United States has begun a programme to test nearly one-third of all newborn babies for the presence of antibodies to human immunodeficiency virus (HIV), the virus causing AIDS.

The study will provide information on the prevalence of HIV infection that is more representative of the general population than that being gathered elsewhere. Other studies are focusing on military recruits, patients at selected hospitals, women attending prenatal testing and abortion clinics and people seeking treatment at sexually transmitted disease clinics.

The tests will be administered as part of a standard series of blood tests to screen for metabolic disorders and infectious diseases that are performed shortly after birth. The results of the tests will be completely anonymous: the mother will not be told whether the results are positive or negative, and the data reported to the US Centers for Disease Control will contain only the mother's age and race. The zip code of the mother's address will be recorded so that regional assessments may be made.

Because there is no cure for AIDS, it is not considered unethical to perform anonymous blood tests for HIV without notifying the donor of the results. Anonymous testing is supported by both homosexual rights groups and the American Civil Liberties Union because it guarantees that the test results cannot be used to discriminate against individuals who test positive. Plans for a random seroprevalence survey of 45,000 US households which were announced at the Third International Conference on AIDS last year, and a 'pilot study' for the random survey based in Washington D.C., have been held up by protests over possible discrimination.

The newborn study is based on one begun in Massachusetts in 1986, which revealed that 2.1 in every 1,000 babies born alive in that state were infected with HIV. Thirty US states and the District of Columbia are expected to participate in the new study, so that a third of the babies born next year in the United States, estimated to number about 3.9 million, will be tested.

The state of New York also began testing newborn infants for antibodies to HIV last year (see Nature 328, 567; 1987). The New York study has so far shown a statewide infection rate of 8.6 in 1,000 and an infection rate for New York City of 16.4 in 1,000 .

Carol Ezzell 